\title{
SKOR KEBOCORAN VASKULER SEBAGAI PREDIKTOR AWAL SYOK PADA DEMAM BERDARAH DENGUE
}

\section{(VASCULAR LEAKAGE SCORE AS THE EARLY PREDICTOR OF SHOCK IN DENGUE HEMORRHAGIC FEVER)}

\author{
Tatty Ermin Setiati, Anastasia Retnaningsih, Mohmad Supriatna, Agustinus Soemantri \\ Bagian IImu Kesehatan Anak Fakultas Kedokteran Universitas Diponegoro / Rumah Sakit Dr. Kariadi (RSDK) Semarang
}

\begin{abstract}
The prediction of shock in Dengue Hemorrhagic Fever is difficult to made, hence, is difficult to detect shock as early as possible. This results in delayed management and ultimately can cause death. Serum levels of protein, albumin, hematocrit, and PEI which are markers of vascular leakage hoped to be able to be used as predictor of shock in DHF. The aim of this study was to develop a scoring system, the Vascular Leakage Score (VLS) that could be used as the predictor of shock and to define the probability of shock from each total score. This was a cross-sectional, observational analytic study, in RSDK, Semarang from 2001-2003. The samples were 138 children with DHF, aged 3-14 years old, divided into 52 cases of DHF without shock, and 76 cases of Dengue Shock Syndrome. Serum levels of protein, albumin, $P E I$, and hematocrit were obtained at admission. Then, a classification was made upon the four parameters mentioned above, based on the ROC curve analysis from the previous studies, and based on the WHO's criteria. To develop a formula for VLS, we gave points-weight for each parameter to calculate the $\beta$-coefficient, then continued with calculation of DSS probability based on total combination of the four categories above, using a logistic-regression analysis of multivariate. Vascular Leakage Score had an excellent ability to predict shock in DHF, with an area under curve of $90 \%$. $V L S$ equation $=23 \times H t+21 \times P E I+33 \times$ total protein $+10 \times$ albumin. The cut-off point for DSS was 125, i.e. VLS $>125$ had a risk of shock 26.9 times higher than VLS $\leq 125$. It was concluded that the Vascular Leakage Score (VLS) could be used to predict the development of shock in $D H \bar{F}$ patients.
\end{abstract}

Keywords: Dengue Hemorrhagic Fever, Vascular leakage Score, Shock

\section{PENDAHULUAN}

Infeksi virus dengue mempunyai spektrum klinis yang luas, dari ringan sampai berat. Berdasarkan jumlah kasus Demam Berdarah Dengue (DBD), Indonesia berada di peringkat kedua dibawah Thailand. Pada stadium dini sulit untuk membedakan infeksi ringan dari infeksi berat $(1,2)$. Sedangkan tingkat kematian Sindrom Syok Dengue (SSD) di Rumah Sakit Dr. Cipto Mangunkusumo (RSCM) masih tinggi, sekitar $13,2 \%$ (3). SSD merupakan infeksi dengue berat yang mengharuskan pasien dirawat inap dengan angka kematian tinggi dan bermakna $(1,2)$. Angka kematian DBD berat (SSD dengan syok berkepanjangan, syok berulang, perdarahan masif) di RS Dr Kariadi Semarang selama 4 tahun sampai tahun 2000 adalah dari 5,7\% menjadi $50 \%$ (4). Hal ini disebabkan karena kesulitan memprediksi perjalanan klinis dari DBD, terutama memprediksi apakah pasien menjadi syok atau tidak, menyebabkan keterlambatan deteksi syok pada stadium dini, sehingga akhirnya menyebabkan keterlambatan pengelolaan yang

Jurnal Kedokteran Brawijaya, Vol. XXI, No.1, April 2005 Korespondensi: Tatty Ermin S; Laboratorium IImu Kesehatan Anak FK Undip/ RS. Dr. Kariadi Semarang, telp. 0248414296; email: tatty@smg.melsa.net.id mengakibatkan komplikasi seperti perdarahan dan disfungsi organ ganda, akhirnya meningkatkan angka kematian.

Sel endotel kapiler diperkirakan berperan penting dalam patogenesis DBD, dan sering menjadi subyek penelitian invitro. Hal ini disebabkan kebocoran vaskuler dan trombositopeni adalah patognomonik pada $\mathrm{DBD}$, dan berhubungan dengan gangguan integritas endotel kapiler $(5,6,7)$. Peran dan fungsi sel endotel pada inflamasi dipengaruhi stimulasi sitokin (IL-1, TNF-a, IL-6, IL-8), virus, bakteri, komplek imun, dan aktivasi sel $\mathrm{B}$ dan sel $\mathrm{T}$, menyebabkan aktivasi endotel.

Patofisiologi utama yang membedakan demam dengue dari $\mathrm{DBD}$ adalah adanya peningkatan permeabilitas vaskuler pada DBD, yang menyebabkan hilangnya sejumlah plasma dari ruang intravaskuler masuk ke ruang interstisial, yang mengakibatkan peningkatan hematokrit, hipoproteinemia dan menyebabkan efusi serosa di rongga pleura, perikardium dan peritoneum $(8,9)$. Dengan mengetahui titik potong parameter kebocoran vaskuler akan meningkatkan kewaspadaan saat mengelola pasien, juga membantu dalam menentukan parameter yang murah dan baik dalam memprediksi perkembangan syok.

Diperlukan prediktor yang akurat untuk memprediksi perjalanan klinis DBD, sehingga dapat dilakukan pengukuran dini yang adekuat untuk mencegah pasien ke 
stadium DBD yang lebih berat. Berdasarkan pemikiran ini diperlukan parameter yang diambil dari patofisiologi utama DBD, perdarahan dan kebocoran vaskuler. Berdasarkan penelitian Tatty (2004), variabel seperti hematokrit, kadar protein, kadar albumin dan IEP merupakan parameter kebocoran vaskuler yang bermakna (10)

Tujuan penelitian ini adalah menentukan skor kebocoran vaskuler yang dapat dijadikan prediktor syok pada DBD.

\section{METODE}

Merupakan penelitian belah lintang, observasional analitik, yang mengukur kadar protein, hematokrit, efusi pleura dan kadar albumin sebagai prediktor kebocoran vaskuler, berhubungan dengan derajat manifestasi klinik Demam Berdarah Dengue (SSD/bukan SSD). Sampel: pasien DBD, berusia 3-14 tahun, dirawat di RS Dr.Kariadi selama periode 2001-2003. Kriteria inklusi: pasien DBD derajat I - IV(kriteria WHO 1999), dan tes serologi ELISA positif untuk mendeteksi antibodi spesifik $\lg G$ dan $\lg M$, berusia 3-14 tahun dan adanya pernyataan persetujuan mengikuti penelitian dari orangtua.

Besar sampel dihitung dengan menggunakan program PASS (Power Analysis and Sample Size v. 2000), dengan nilai probabilitas insiden SSD berdasarkan perubahan nilai IEP, yaitu 0,5 , dengan $\alpha=0.05$, kekuatan $=$
$80 \%(\beta=0.2$ ), nilai $\mathrm{OR}=2$, sehingga didapatkan jumlah minimal sampel adalah 78 .

Kemudian dibuat pengelompokan untuk masingmasing variabel, berdasarkan kriteria WHO, dan dari perhitungan koordinat kurva Receiver Operating Curve (ROC) dari penelitian sebelumnya.

Analisis data meliputi analisis deskriptif dan tes hipotesis. Pada analisis deskriptif, data disajikan dengan rerata $\pm S D$, frekuensi dan persentase. Tes hipotesis dilakukan dengan menggunakan tes $T$ tanpa berpasangan/tes Mann-Whitney untuk hematokrit, kadar protein, kadar albumin dan indeks efusi pleura (Skor kebocoran vaskuler) antara kelompok SSD dan bukan SSD.

Kemudian ditentukan titik potong skor kebocoran vaskuler untuk insiden SSD pada pasien DBD, menggunakan tes diagnostik kurva ROC. $p \leq 0,05$ dianggap bermakna secara statistik. Interval kepercayaan 95\%(Cl 95\%). Analisis statistik dilakukan dengan menggunakan program SPSS for Windows,v.11,5.

Berdasarkan titik potong pada penghitungan kurva ROC untuk tiap variabel, dapat dibuat perhitungan regresi logistik untuk menentukan koefisien $\beta$. Nilai koefisien $\beta$ dapat digunakam untuk membuat rumus persamaan prediksi. Nilai prediktor dari tiap variabel dapat dijumlahkan untuk menentukan kemungkinan terjadinya syok.

\section{Tabel 1. Karakteristik Pasien DBD Berdasarkan Derajat Penyakit}

Variabel ditampilkan sebagai rerata $( \pm$ SD) atau $n(\%)$ untuk variabel kategori.

\begin{tabular}{|c|c|c|c|}
\hline Variabel & $\begin{array}{c}\text { DBD Non SSD } \\
n=62\end{array}$ & $\begin{array}{l}\text { SSD } \\
n=76\end{array}$ & $p$ \\
\hline Usia & $8,6(2,82)$ & $7,4(3,08)$ & $0,01^{*}$ \\
\hline Berat badan $(\mathrm{kg})$ & $26,3(12,27)$ & $20,6(10,12)$ & $<0,001^{*}$ \\
\hline Tinggi badan $(\mathrm{cm})$ & $126,2(18,00)$ & $118,8(17,44)$ & $0,007^{*}$ \\
\hline BMI & $16,1(5,92)$ & $14,1(4,02)$ & $<0,001^{*}$ \\
\hline \multicolumn{4}{|l|}{ Jenis kelamin } \\
\hline - $\quad$ Laki-laki & $27(36,5)$ & $47(63,5)$ & \\
\hline - $\quad$ Perempuan & $35(54,7)$ & $29(45,3)$ & $0,032^{\prime}$ \\
\hline \multicolumn{4}{|l|}{ Kelompok umur (tahun) } \\
\hline - $\quad 3-6$ & $15(28,8)$ & $37(71,2)$ & \\
\hline $7-10$ & $30(56,6)$ & $23(43,4)$ & \\
\hline - $\quad 11-14$ & $17(51,5)$ & $16(48,5)$ & $0,011^{\prime}$ \\
\hline \multicolumn{4}{|l|}{ Status nutrisional } \\
\hline - $\quad$ Gizi kurang & $21(28,4)$ & $53(71,6)$ & \\
\hline Gizi baik & $36(66,7)$ & $18(33,3)$ & \\
\hline Gizi lebih & $4(57,1)$ & $3(42,9)$ & \\
\hline - $\quad$ Obesitas & $1(33,3)$ & $2(66,7)$ & $<0,001^{\prime}$ \\
\hline
\end{tabular}




\section{HASIL PENELITIAN}

Pada penelitian ini diperoleh 138 anak dengan DBD, berusia 3-14 tahun, dikelompokkan menjadi 52 kasus DBD tanpa syok, dan 76 kasus Sindrom Syok Dengue (SSD), yang terdiri dari 84 laki - laki dan 64 perempuan.

Pada Tabel 1 dapat dilihat bahwa rerata usia penderita SSD $(7,4 \pm 3,08$ tahun) lebih muda secara bermakna $(p=0,01)$ dibandingkan penderita Non SSD $(8,6$ $\pm 2,82$ ). Apabila digolongkan berdasarkan kelompok umur, kejadian SSD lebih sering terjadi pada umur 3-6 tahun. Terdapat perbedaan bermakna kejadian SSD bedasarkan jenis kelamin, laki-laki lebih banyak mengalami SSD dibanding perempuan $(p=0,032)$. Terdapat perbedaan kejadian syok pada DBD berdasarkan status nutrisional, $71,6 \%$ penderita DBD dengan gizi kurang dan $66,7 \%$ penderita dengan obesitas mengalami syok $(p<0,001)$.

Tabel 2. Hematokrit, Indeks Efusi Pleura (IEP), Protein Total dan Kadar Plasma Levels pada Anak dengan DBD, Berdasarkan Derajat Penyakit.

Variabel ditampilkan sebagai rerata $( \pm S D)$, nilai minimum and maksimum.

\begin{tabular}{lccc}
\hline \multicolumn{1}{l}{ Dariabel } & & SSD & $\mathbf{p}^{*}$ \\
\hline Hematokrit (\%) & $38,8(5,36) ; 26,9-50,5$ & $41,8(7,99) ; 10,0-51,9$ & $<0,001$ \\
\hline IEP & $4,41(7,9) ; 0,0-32,8$ & $18,2(14,58) ; 0,0-72,2$ & $<0,001$ \\
\hline Protein total (g/l) & $6,8(0,78) ; 5,0-8,4$ & $5,7(1,55) ; 2,0-9,3$ & $<0,001$ \\
\hline Albumin (g/l) & $3,7(0,49) ; 2,8-5,6$ & $3,1(0,80) ; 1,0-4,6$ & $<0,001$ \\
\hline Keterangan: * tes Mann-Whitney & &
\end{tabular}

Tabel 2 menunjukkan nilai rerata hasil pemeriksaan laboratorium pada penderita DBD. Nilai hematokrit dan indeks efusi pleura (IEP) penderita SSD lebih tinggi secara bermakna dibandingkan penderita Non SSD ( $p<0,001)$, sedangkan kadar protein total dan albumin penderita SSD lebih rendah secara bermakna dibandingkan penderita Non $\operatorname{SSD}(p<0,001)$.

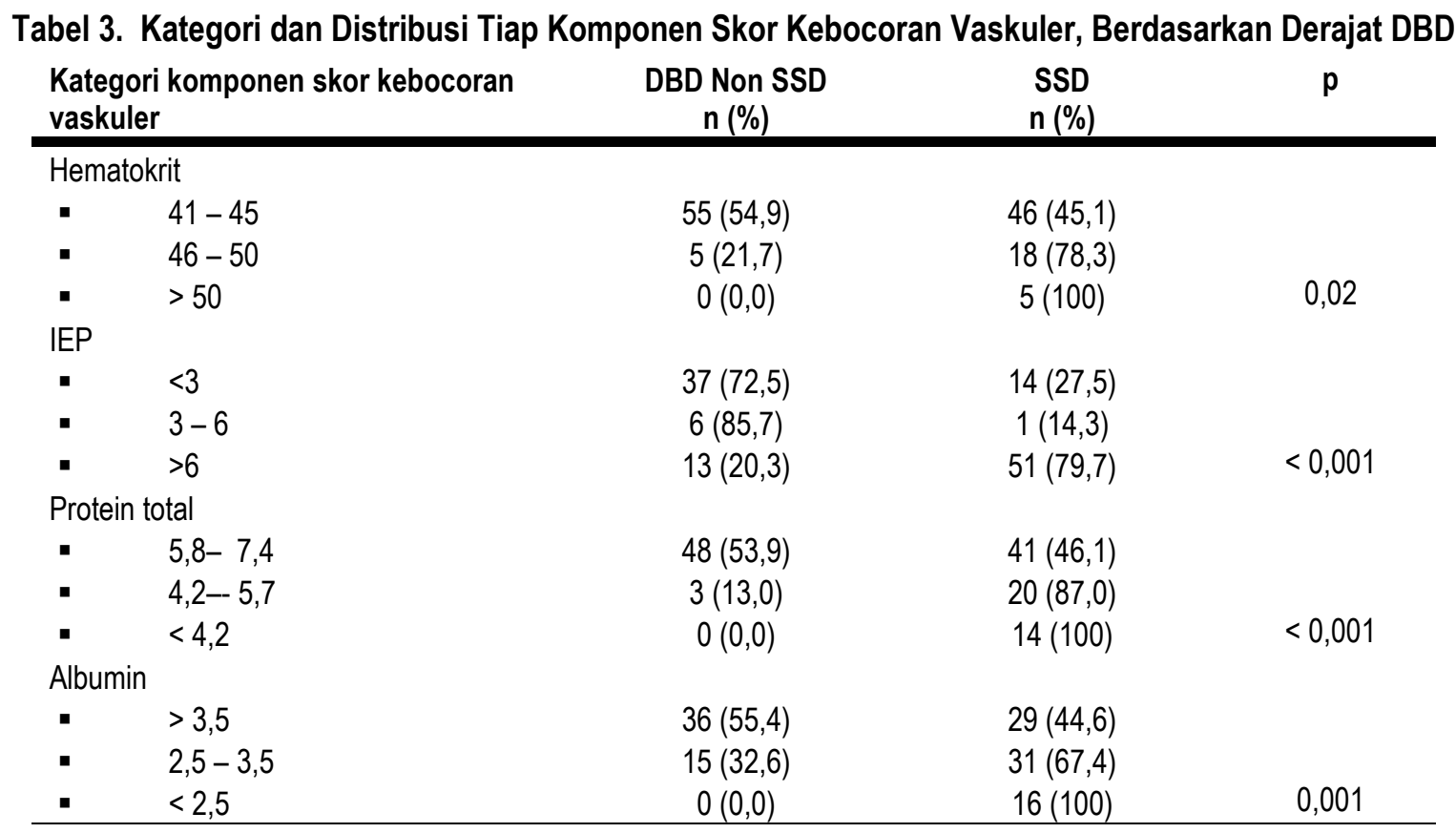

Tabel 3 menunjukkan pengkategorian masing-masing parameter kebocoran vaskuler. Nilai Hematokrit, IEP, protein total, dan albumin masing-masing dikelompokkan menjadi tiga interval kelas. Interval hematokrit ditetapkan berdasarkan derajat hemokonsentrasi pada DBD menurut WHO, interval IEP ditetapkan berdasarkan cutoff poin terjadinya syok pada DBD sesuai dengan hasil penelitian sebelumnya (Tatty ES, IEP $6 \%$ mempunyai OR $>8$ untuk terjadi syok pada DBD). Sedangkan interval protein total dan albumin ditetapkan berdasarkan rentang nilai normal yang dibagi menjadi tiga kelas interval berdasarkan perhitungan statistik. 
Tabel 4. Hasil Tes Regresi Logistik Multivariat, untuk Kategori: Hematokrit, IEP, Protein Total, dan Albumin Plasma untuk Memprediksi SSD

\begin{tabular}{lccccc}
\hline Variabel & $\mathbf{B}$ & $\mathbf{S , E}$, & $\mathbf{p}$ & $\mathbf{O R}$ & $\mathbf{9 5 , 0 \%} \mathbf{~ C l}$ \\
\hline Hematokrit & 1,176 & 0,640 & 0,07 & 3,2 & $0,9 \mathrm{~s} / \mathrm{d} 11,4$ \\
IEP & 1,097 & 0,284 & $<0,001$ & 3,0 & $1,7 \mathrm{~s} / \mathrm{d} 5,2$ \\
Protein total & 1,695 & 0,739 & 0,02 & 5,4 & $1,3 \mathrm{~s} / \mathrm{d} 23,2$ \\
Albumin & 0,518 & 0,532 & 0,3 & 1,7 & $0,6 \mathrm{~s} / \mathrm{d} 4,8$ \\
konstanta & $-6,205$ & 1,328 & & & \\
\hline \multicolumn{2}{l}{ (Daerah di bawah kurvalArea Under the Curve=AUC) $=0,9$} \\
\hline
\end{tabular}

Tabel 4 menunjukkan hasil regresi multivariat bahwa IEP dan protein total merupakan faktor risiko terjadinya syok pada DBD ( $p<0,05$ dan $O R>2)$, walaupun hematokrit mempunyai nilai $p=0,07$, tetapi $O R>2,0$ sehingga tetap dimasukkan sebagai faktor risiko. Sedangkan albumin tidak terbukti sebagai faktor risiko ( $p=0,3$ dan OR 1,7), tetapi tetap dimasukkan dalam analisis selanjutnya (formulasi skor kebocoran vaskuler) karena secara klinis nilai albumin sangat berperan dalam mempertahankan tekanan hidrostatik (onkotik) intravaskuler yang sangat berpengaruh pada kebocoran vaskuler.

Tabel 5 menunjukkan pembobotan (skor) masingmasing variabel kebocoran vaskuler, semakin besar skor semakin besar peluang terjadinya syok.

Tabel 5. Skor Kebocoran Vaskuler

\begin{tabular}{lccc}
\hline Parameter Laboratorium & \multicolumn{3}{c}{ Skor } \\
\cline { 2 - 4 } & $\mathbf{1}$ & $\mathbf{2}$ & $\mathbf{3}$ \\
\hline Hematokrit $(\%)$ & $41-45$ & $46-50$ & $>50$ \\
IEP & $\leq 3$ & $3-6$ & $>6$ \\
Protein total $(\mathrm{g} / \mathrm{dL})$ & $5,8-7,4$ & $4,2-5,7$ & $<4,2$ \\
Albumin $(\mathrm{g} / \mathrm{dL})$ & $>3,5$ & $2,5-3,5$ & $<2,4$ \\
\hline SKV = 23 x skor hematokrit + 21 x skor IEP + 33 x skor protein total + $\mathbf{1 0}$ x skor albumin \\
\hline
\end{tabular}

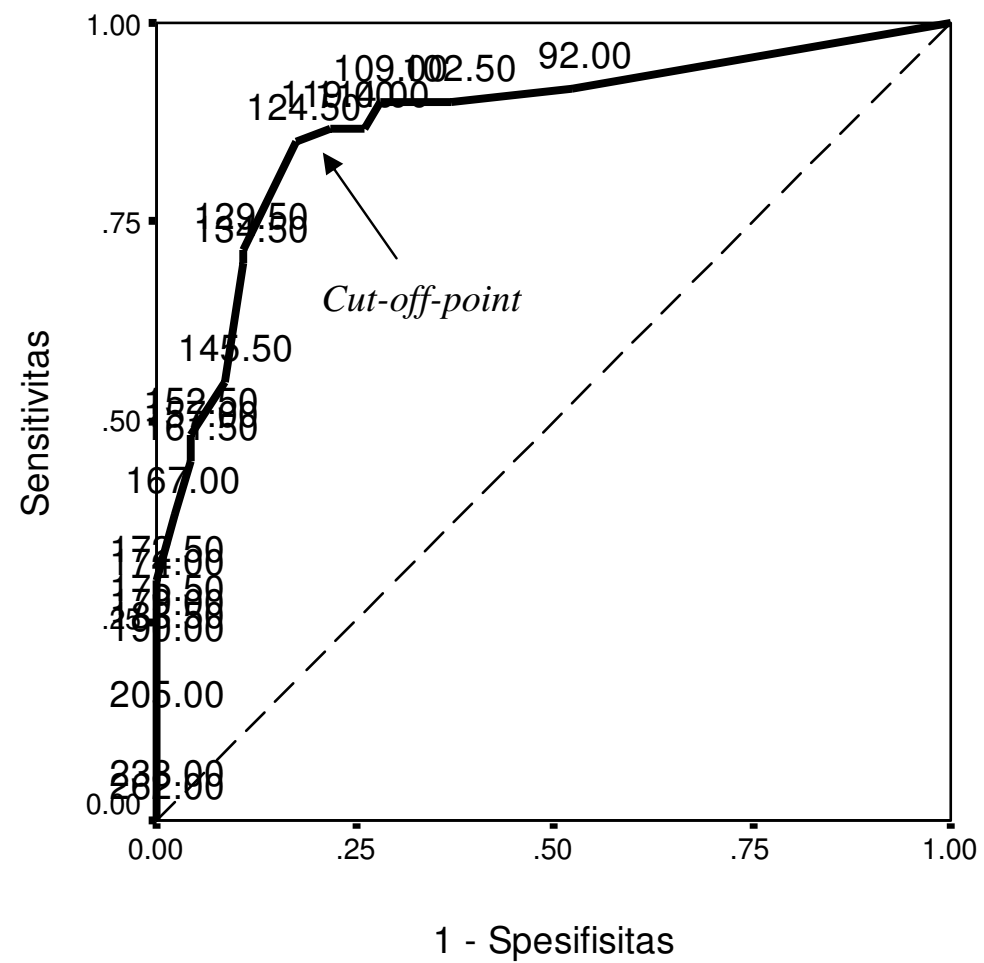

Gambar 1.Kurva ROC skor kebocoran vaskuler untuk memprediksi perkembangan syok pada SSD. $A U C=0,9(95 \% \mathrm{Cl}=$ $0,8$ to 0,9$)$ 
Pada kurva ROC dapat dilihat bahwa cuttoff poin SKV sebagai prediktor syok pada DBD adalah 124,50. Pada analisis selanjutnya (Tabel 7) SKV 125 mempunyai sensitivitas $85,0 \%$ dan spesifisitas $82,6 \%$ dengan OR 26,9 (Cl 95\% : 9,5-76,2).

Tabel 6. Hasil Tes Diagnostik dan Nilai OR untuk Skor Kebocoran Vaskuler

\begin{tabular}{|c|c|c|c|c|}
\hline $\begin{array}{l}\text { Kategori skor: } \\
\text { kebocoran vaskuler }\end{array}$ & & $\begin{array}{c}\text { DBD tanpa Syok } \\
\mathrm{n}(\%)\end{array}$ & $\begin{array}{l}\text { SSD } \\
\mathrm{n}(\%) \\
\end{array}$ & $\begin{array}{c}\text { OR } \\
(95 \% \mathrm{Cl})\end{array}$ \\
\hline Skor $\leq 125$ & & $38(80,9)$ & $9(19,1)$ & 1 \\
\hline Skor > 125 & & $8(13,6)$ & $51(86,4)$ & $26,9(9,5 \mathrm{~s} / \mathrm{d} 76,2)$ \\
\hline$\chi^{2}=48,225$ & & $d f=1$ & & $p<0,001$ \\
\hline Sensitivitas & $=$ & $85,0 \%(76,0 \mathrm{~s} / \mathrm{d} 94,0)$ & & \\
\hline Spesifisitas & $=$ & $82,6 \%(71,6 \mathrm{~s} / \mathrm{d} 93,6)$ & & \\
\hline Nilai prediksi positif & $=$ & $86,4 \%(77,7$ s/d 95,2) & & \\
\hline Nilai prediksi negatif & $=$ & $80,9 \%(69,6$ s/d 92,1$)$ & & \\
\hline
\end{tabular}

\section{DISKUSI}

Berdasarkan hasil penelitian ini, status gizi kurang dan obesitas mempunyai risiko terjadinya syok lebih besar secara bermakna dibandingkan dengan gizi baik. Pada beberapa penelitian terdahulu, penderita dengan obesitas mempunyai risiko lebih besar untuk mengalami syok. Status gizi sering dikaitkan dengan respon sistem imun yang berpengaruh terhadap beratnya DBD (8). Status gizi kurang belum ada penelitian lain, diduga berhubungan dengan depresi sistem imun, sehingga diperlukan penelitian lebih lanjut.

Patofisiologi utama dari DBD adalah kebocoran vaskuler. Pada SSD kebocoran vaskuler yang terjadi lebih berat dari Non SSD, hal ini sesuai dengan penelitian sebelumnya $(10,11)$.

Seluruh variabel kebocoran vaskuler, kecuali albumin merupakan prediktor syok pada DBD, sesuai dengan patofisiologi syok pada DBD akibat kebocoran vaskuler. Walaupun secara multivariat albumin tidak merupakan faktor risiko, tetapi secara univariat berbeda bermakna pada SSD dan Non SSD, sehingga masih tetap dimasukkan pada analisis selanjutnya.

Formulasi SKV (SKV $=23 \mathrm{x}$ skor hematokrit $+21 \mathrm{x}$ skor IEP $+33 \times$ skor protein total $+10 \times$ skor albumin) dapat dipergunakan dalam penatalaksanaan DBD untuk meningkatkan kewaspadaan dan antisipasi terjadinya syok. Penilaian SKV harus dilakukan pada saat penderita masuk rumah sakit dan diulang selama fase akut DBD (72 jam berikutnya). Penilaian SKV dapat dilakukan di semua rumah sakit tipe C.

\section{KESIMPULAN}

Skor kebocoran vaskuler dapat digunakan sebagai prediktor syok pada demam berdarah dengue.

\section{SARAN}

Diperlukan penelitian lebih lanjut, terutama penelitian multisenter, untuk memvalidasi skor kebocoran vaskuler, menggunakan jumlah pasien dan kasus yg lebih banyak untuk mendapatkan subyek yang lebih lengkap pada tiap spektrum dari tiap sub kategori skor.

\section{UCAPAN TERIMA KASIH}

Para penulis berterimakasih pada penelitian kolaborasi tentang demam berdarah dengue antara Indonesia dan Belanda dan RS Dr.Kariadi Semarang atas kesempatan dan dukungan terhadap penelitian ini.

\section{DAFTAR KEPUSTAKAAN}

1. Brahmarapravati N. Pathology of Dengue Haemorrhagic Fever. In: Thongcharoen P, ed. Monograph on Dengue/ Dengue Hemorrhagic Fever. New Delhi: WHO SEARO Publication; 1993; 22: $27-29$.

2. Suroso T, Umar Al. Epidemiologi dan Penanggulangan Penyakit Demam Berdarah Dengue (DBD) di Indonesia saat ini. In: Sri Rejeki H, Hindra Irawan S, Penyunting. Demam Berdarah Dengue. Jakarta: Balai Penerbit FKUI; 1999; 14-31.

3. Hadinegoro SR. Telaah Endotoksemia pada Perjalanan Penyakit Demam Berdarah Dengue: Perhatian Khusus pada Syok, Produksi TNF $\alpha$, Interleukin - 6, dan Sebagai Prediktor Demam Berdarah Berat. [Disertasi]. Doktor. Jakarta: Program Pasca Sarjana UI. 1996.

4. Tatty ES, Soemantri AG, Anggoro DBS, Bukit P. Severe Dengue Haemorrhagic Fever in Dr Kariadi- Semarang, Cental of Java. Pressented in KONIKA X, Bukittinggi 1996 (unpublished). 
5. Anderson R, Wang S, Osiowy C. Activation Endothelial Cells Via Antibody- Enhanced Dengue Virus Infection of Peripheral Blood Monocytes. J. Virol 1997; 71: 4226-4232.

6. Sutaryo. Perkembangan Patogenesis Demam Berdarah Dengue. In: Sri Rejeki H, Hinra Irawan S, (Ed). Demam Berdarah Dengue. Jakarta: Balai Penerbit FKUI; 1999; 32-43.

7. Avirutnan P, Malasit P, Seliger B. Dengue Virus Infektion of Human Endothelial Cells Leads to Chemokines Production, Complement Activation and Apoptosis. J. Immunol 1998; 161: 50-88.

8. Peres JGR. Clark GG, Gubler DJ, Senders EJ, Vomdam AV. Dengue and Dengue Haemorrhagic Fever. Lancet 1998; 352: 971-77.

9. Gubler DJ. Dengue and Dengue Haemorrhagic Fever. Clin. Microbiol. Rev 1998; 480-496.

10. Tatty ES. Faktor Hemostasis dan Kebocoran Vaskuler sebagai Faktor Diskriminan untuk Memprediksi Terjadinya Syok pada DBD. [Disertasi]. Semarang: Universitas Diponegoro. 2004; 74.

11. Suharti C. Dengue Haemorrhagic Fever in Indonesia, The Role of Cytokines in Plasma Leakage, Coagulation and Fibrinolysis. [Disertation].Katholieke: Universiteit Nijmegen. 2001: 137-139. 